\title{
Distinction criteria for fiscal torts
}

\author{
KATARZYNA ŁUCARZ \\ Department of Law on Misdemeanors, Criminal Fiscal and Criminal Business \\ Faculty of Law, Administration, and Economics \\ University of Wroclaw, Poland
}

The existing bipartition of torts into fiscal offences and fiscal petty offences is a relatively new solution, introduced into Polish legislation by the Penal Fiscal Act of 26.10.1971. ${ }^{1}$ Previously, there was a slightly different taxonomy which included fiscal offences and fiscal misdemeanours. It should be noted that this bipartition was also applied as a response to the transformations in penal fiscal law. The first two penal fiscal acts form-

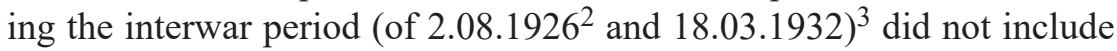
any formal division of torts at all, within the meaning of their classical tripartition into felonies, misdemeanors, and petty offences. As a result, there was only one category of fiscal offences within which there was distinguished, mainly for practical reasons, a so-called breach of order that involved pecuniary penalties. However, it did not involve fiscal offences resulting in a reduction of the State Treasury's revenue. Only since the Decree of the President of the Republic of Poland of 3.11.1936 - Penal Fiscal $\mathrm{Law}^{4}$ was there applied the division of fiscal offences into two categories: fiscal misdemeanours and fiscal petty offences, the latter were included into fiscal offences and involved pecuniary penalties. This state

${ }^{1}$ I.e. Journal of Laws [Dz.U.] of 1984 No. 22, item 103 as amended.

2 Journal of Laws [Dz.U.] of the Republic of Poland No. 105, item 609.

3 Journal of Laws [Dz.U.] of the Republic of Poland No. 34, item 355.

${ }^{4}$ Journal of Laws [Dz.U.] of the Republic of Poland No. 84, item 581. 
of affairs continued uninterrupted until 1971. By the above-mentioned Penal Fiscal Act of 26.10.1971, the idea of including fiscal misdemeanors and fiscal petty offences into a common category of fiscal offences was finally rejected. Instead, there was applied a bipartition of torts into fiscal offences and fiscal petty offences, which is continued currently in the Penal and Fiscal Code in force. ${ }^{5}$ Consolidating the above-mentioned bipartition of penal fiscal torts, in Title I Chapter 1, 2, and 5 of the General Part of the Act on fiscal offences and fiscal petty offences, there were formulated general conditions of criminal liability both for fiscal offences and fiscal petty offences, and Chapter 3 and 4 focus respectively on fiscal offences and fiscal petty offences. Interestingly, a fiscal offence and a fiscal petty offence is defined in Article 53 (Chapter 5) which includes the explanation of legal terms. Section 2 of Article 53 of the Penal and Fiscal Code implies that fiscal offences are those acts in the Code that are prohibited under pecuniary penalty imposed as day-fine units, penalty of restricted liberty or penalty of deprivation of liberty. According to Section 3 of Article 53, a fiscal petty offence is an act that in the Penal and Fiscal Code is subject to pecuniary penalty, when the value of the subject of the act or the reduced, or exposed to risk of reduction, public law liability does not exceed five times the minimum remuneration at the time when the act was committed (Section 3, first sentence), and an act which is considered a fiscal petty offence in the Code (Section 3, second sentence). In practice, the legislator uses the expression "is subject to pecuniary penalty for a fiscal petty offence", in which the penalty is naturally expressed as an amount, according to Article 47 Section 1 of the Penal and Fiscal Code.

It is worth adding that currently there is no evidence of liability diversification of responsibilities in terms of fiscal offences and petty offences. However, the literal content of Article 1 Section 1 of the Penal and Fiscal Code could imply something else. Only with regard to liability for fiscal offences, the legislator uses the term "penal" and evidently avoids this adjective to define liability for fiscal petty offences. Nevertheless, liability for fiscal offences and fiscal petty offences is the same. Primarily, it is due to the fact that the principles of liability defined in Chap-

5 I.e. Journal of Laws [Dz.U.] of 2017, item 2226. 
ter 1 of the Penal and Fiscal Code are common for both types of penal fiscal torts. The concepts of "fiscal offence" and "fiscal petty offence" almost always occur together. Moreover, the differences in the category of petty offences, which include only pecuniary penalties, imposed not in the form of day-fine units, as for offences, but as an amount; a significant reduction of possibilities of ruling on other measures (penal and preventive measures); a clean criminal record in the time period before committing a crime; and the forms of accessorial liability other than the offenders; and finally justification of the experiment and shorter periods of limitation as well as expungement — are rather less significant. ${ }^{6}$ They result from fiscal petty offences of minor significance. Nonetheless, omitting the adjective "penal" with regard to liability for fiscal petty offences does not provide any legal basis for the conclusion that it is a different type of liability. It can only be justified by the fact that under the generally applicable law on petty offences the legislator also does not use the term "penal liability". However, there can be no doubt that liability for petty offences under the generally applicable law is penal liability but with reduced legal consequences. The recommended approach is by no means suppressed by the fact that the Penal and Fiscal Code has recently introduced an exemption concerning fiscal petty offences in the form of proceedings by police penal orders, although penal fiscal law became judicial law, according to constitutional requirements. However, it is dependent on the acceptance of the offender. Therefore, the lack of acceptance starts the appropriate court proceedings in fiscal petty offences. Also, only the court is a competent authority that can prospectively cancel a penalty notice. Therefore, this type of proceeding is not a sufficient argument in favour of the thesis on the different natures of liability for fiscal offences and petty offences. ${ }^{7}$

Turning to the issue of distinguishing of fiscal petty offences, while taking into consideration particularly Article 53 Section 3 of the Penal and Fiscal Code and, consequently, also Article 53 Section 8 of the Penal and Fiscal Code and the provisions of the General Part of the Code, it is easy to notice that the legislator uses the following criteria:

${ }^{6}$ L. Wilk, J. Zagrodnik, Prawo karne skarbowe, Warszawa 2009, pp. 37-39.

${ }^{7}$ Likewise but with reference to common offences A. Marek, [in:] System prawa karnego. Zagadnienia ogólne, vol. 1, ed. A. Marek, Warszawa 2010, p. 46. 
1. The amount of reduced, or exposed to risk of reduction, public law liability or the value of the subject of the offence that does not exceed the statutory threshold;

2. An act of lesser significance;

3. Formalism in violation of provisions. ${ }^{8}$

The first two criteria provide a structure of wobblers in the Penal and Fiscal Code, which means that an act that is uniform in type and of identical general features is divided "across" and on this basis it is separated into a part that constitutes a fiscal offence and a part which is equivalent to a fiscal petty offence. It should be noted that this method is used by the legislator mainly on the grounds of the Penal and Fiscal Code. Over $3 / 4$ of prohibited acts are wobblers. And it is understandable, as for both structures — statutory threshold and act of lesser significance — there are applied measures of the significance of acts concerning economic phenomena and it is also recognised that penal fiscal blanket dispositions cover very diversified behavior in terms of characteristic gravity. More importantly, a predominance of wobblers is another argument in favour of the lack of a significant difference in the nature of liability for a fiscal offence and a fiscal petty offence. ${ }^{9}$ For both categories of fiscal torts, there is the same type of liability. The last criterion of distinguishing fiscal petty offences from fiscal offences has relatively little use on the grounds of the Penal and Fiscal Code. The criterion covers in the Penal and Fiscal Code the cases of penalising only the violation of some formal obligations arising from financial law, which does not result in a reduction of public law liabilities. The legislator formulates a fiscal petty offence so as not to consider it a fiscal offence. Therefore, the legislator does not create a structure of wobblers. On this basis, the legislator distinguishes a little group of acts which are either fiscal petty offences or fiscal offences.

Discussing the term "statutory threshold" it is necessary to refer first to Article 53 Section 6 of the Penal and Fiscal Code. According to this

8 T. Grzegorczyk, Kodeks karny skarbowy. Komentarz, $2^{\text {nd }}$ ed., Warszawa 2001, p. 212. To the amendment of 2005 The Penal and Fiscal Code provided one more criterion of distinguishing fiscal petty offences - unintentionality. However, it played a negligible role in the background of the other two.

${ }^{9}$ L. Wilk, Szczególne cechy odpowiedzialności za przestępstwa i wykroczenia skarbowe, Katowice 2006, p. 46. 
Article "statutory threshold" discussed in Title I Section II - the Specific Part is the amount stipulated in Section 3, the first sentence. Therefore, there is considered the value of the subject of the act or the amount of the reduced, or exposed to risk of reduction, public law liability which does not exceed five times the minimum remuneration at the time when the act was committed. Only a brief analysis of this provision leads to the conclusion that "cutting acts across" with this quantitative criterion should not cause serious difficulties in practice. It proves, after all, an undoubted advantage of unambiguity. It is mainly because the recognition of the content of this provision is eased by the fact that the legislator included characteristic definitions in the glossary of statutory terms and definitions. Those terms include: the value of the subject of the act, the reduced, or exposed to risk of reduction, public law liability and the minimum remuneration.

The value of the subject of the act is significant particularly in those cases when the act does not involve a reduction or exposing to risk of reduction of the public law liability. ${ }^{10}$ According to Article 53 Section 17 of the Penal and Fiscal Code, the value of the prohibited act is defined according to its average market price in the territory of the Republic of Poland, considering the wear level, and if the data is missing - based on the estimation. Such an estimation, as a circumstance requiring specialised knowledge, should be conducted according to Article 193 of the Criminal Procedure Code in connection with Article 113 Section 1 of the Penal and Fiscal Code by an expert. ${ }^{11}$ Of course, the price is estimated on the basis of the time when the prohibited act was committed, and if impossible - the time of its disclosure.

When estimating the equivalent monetary value of the subject of forfeiture (the value of the subject to be paid in compensation in the absence of forfeiture), when the subject was destroyed or lost, it is possible

${ }^{10}$ The value of the subject of an act, apart from the fact that it constitutes the criterion of distinction between a fiscal petty often and a fiscal offence, is also applied to distinguish between fiscal offences of a basic nature and privileged offences due to a socalled low value (Article 53 Section 14 of the Penal and Fiscal Code), and is also the basis for extraordinary aggravation of the penalty in case of a so-called high or low value (Article 53 Section 15 and 16 of the Penal and Fiscal Code in connection with Article 37 and 38 of the Penal and Fiscal Code).

${ }^{11}$ Z. Siwik, Systematyczny komentarz do ustawy karnej skarbowej. Część ogólna, Wrocław 1993, p. 176. 
to determine the value approximately if it is impossible to do it precisely (Article 32 Section 2 of the Penal and Fiscal Code). Therefore, the legislator provided some margin of discretion, although the judicial authority should explain in the justification of the ruling the criteria adopted when estimating the equivalent amount of the subjects of forfeiture.

According to the Code, a public law liability is a state or local government liability which is a subject of a fiscal offence or a fiscal petty offence. A state liability is a tax which constitutes the state budget income, a liability from subsidy clearance or customs duty, and a local government liability - a tax which constitutes the local government unit income or a liability from subsidy clearance (Article 53 Section 26 of the Penal and Fiscal Code). A public law liability, including a tax, is also a liability which constitutes the general budget revenue of the European Communities or the budget governed by the Communities or on their behalf, according to the provisions of EU law, binding for the Republic of Poland, whose liability is a subject of a fiscal offence or a fiscal petty offence (Article 53 Section 26a of the Penal and Fiscal Code). It should be noted that the term "public law liability" is reserved only for the General Part of the Penal and Fiscal Code. The Specific Part of the Code makes a reference to exposing to risk of reduction of a determined State Treasury liability or a local government liability (e.g., a tax, duty), or "exposing to risk of reduction of the public finance". In general, "public law liability" is included in many provisions of the procedural and executive parts of the Penal and Fiscal Code (Title II and Title III of the Code).

When it comes to a public law liability reduced by a prohibited act, it is an amount of money that the person liable did not pay in whole or in part, which caused a financial loss (Article 53 Section 27 of the Penal and Fiscal Code). The reduced liability is the public law liability that the person liable did not pay, despite the obligation, therefore, it is only the difference between the amount paid and the amount due in accordance with the provisions, or the whole liability amount that the offender did not pay at all, despite the obligation. As a result, a reduction is only when a financial loss has already taken place. The amount of the reduction can result in qualifying the act as a fiscal petty offence within the statutory threshold. 
An exposure to risk of reducing a public law liability by a prohibited act is to cause a particular danger of such a reduction, which means that a financial loss is highly probable, although it does not have to take place (Article 53 Section 28 of the Penal and Fiscal Code). In contrary to a reduced liability included in Article 53 Section 27 of the Penal and Fiscal Code, in Section 28 there is defined "exposure to reduction" of a public law liability, therefore, causing only a particular danger of reduction which is connected with a high risk of a loss, despite the fact that it has not yet taken place. Also in this case, the amount (quantity) exposed to risk of reduction is a feature qualifying an act as a fiscal petty offence within the statutory threshold. ${ }^{12}$

Finally, the minimum remuneration which, in accordance with the amended text of Article 53 Section 4 of the Penal and Fiscal Code, was defined as remuneration due for the work performed, based on the Act of 10.10.2002 on the minimum remuneration for the work performed. ${ }^{13}$ Pausing for a moment at this mechanism of identification of fiscal petty offences, it should be noted that Article 53 Section 4 of the Penal and Fiscal Code in its original version did not determine "minimum remuneration" but "minimum monthly salary". Therefore, it referred not only to the Labour Code but primarily to its executive regulations which determine and valorise the remuneration. Needless to say, this reference to the provisions of lower rank than the Act (such a structure was also used in Article 53 Section 3 and 6 of the Penal and Fiscal Code) caused the greatest controversies. This solution was considered noncompliant with the Basic Law that requires a statutory specification of the features of an act committed (Article 42 Section 1 of the Constitution of the Republic of Poland). This means that the fiscal act itself has to define all features of acts under penalty in a competent, precise, and unambiguous way. ${ }^{14}$ However, the liability that on the grounds of the Penal and Fiscal Code is penalised did not result from the Act in its every aspect. Additionally, it was emphasised that it interfered with Article 93 of the Constitution, due to the fact that the regulations are of an internal nature and are binding

12 T. Grzegorczyk, op. cit., pp. 229-230.

13 I.e. Journal of Laws [Dz. U.] of 2017, item 847.

14 The Judgement of the Constitutional Tribunal of 26 April 1995, K 11/94, OTK 1995, no. 1, item 12 . 
only for organisational units subordinate to the authority which issues those acts. ${ }^{15}$ Therefore they cannot constitute the basis of the decision towards the citizens, legal persons, and other entities. Moreover, the lack of the method of estimating and valorising of the minimum remuneration in the Labour Code, e.g., according to the data of the Statistical Office, exposed the discussed solution to the allegation of non-constitutionality. According to Article 65 Section 4 of the Constitution of the Republic of Poland, the minimum remuneration for the work performed or the method of estimating it should be determined by the general applicable law and not an act of low-rank. ${ }^{16}$

Obviously, the same use of the criterion of minimum remuneration by which the legislator defines the line between a fiscal offence and a petty offence would be difficult to consider unacceptable. The Constitutional Tribunal decided that the minimum remuneration can function and it actually functions on the grounds of criminal law as a unit of the value measurement. It is nothing other than an estimation of the basket of consumer goods essential for life. The content of the basket basically remains unchanged, the real value does not change either. However, the nominal value is growing. Therefore, indicating the current nominal value is only a matter of facts. It can be stated that in terms of prohibitions formulated by criminal law, the estimation of the amount is only a factor objectifying the certain real, shaped economical value. A similar approach is included in the doctrine of criminal law, according to which a regulation of criminal law that requires a complement by descriptive explanations of the terms used in the disposition is not a blanket provision but a provision with a complete disposition including normative features. ${ }^{17}$ It is also emphasised that an additional argument for admissibility and even a clear need for referring to indicators in penal fiscal law related to economic phenomena is the protected subject matter relevant to this law, which means "the interest and financial order of the state, or more broadly — public finance". It constitutes a common feature of

15 J. Michalski, Komentarz do kodeksu karnego skarbowego. Tytut I. Przestępstwa skarbowe i wykroczenia skarbowe, Warszawa 2000, p. 116.

16 F. Prusak, Prawo i postepowanie karne skarbowe, $2^{\text {nd }}$ ed., Warszawa 2002, p. 68.

17 R. Dębski, Pozaustawowe znamiona przestępstwa, Łódź 1995, p. 126. 
all fiscal prohibited acts which stands for the autonomous nature of this branch of law.

The above-mentioned approach of the Constitutional Tribunal ${ }^{18}$ remains valid, although the legislator withdrew the criterion of the minimum monthly salary as an indexing rate of certain values. ${ }^{19}$ Replacing it with "minimum remuneration", which is estimated on the basis of the law, the legislator dissented definitely from the allegations regarding non-constitutionality, formulated previously against the indexing rate. By implementing those changes for the estimation and functioning of the minimum remuneration, the legislator equally prevented this value from inflexibility. A clear indication that it concerns the remuneration estimated on the basis of the Minimum Remuneration Act means that currently it is impossible to refer in this case to the structure adopted in Article 25 of this Act, i.e., to equate the minimum remuneration for the work performed with "the minimum remuneration for the work performed by employees" which was fixed as an inflexible amount of 760 PLN. Moreover, a dynamic nature of this criterion is provided by a specific procedure of fixing the minimum remuneration, which causes actually a constant growth of the remuneration. It makes the line between fiscal torts movable. According to Article 2 Section 1 of the Minimum Remuneration, the amount is annually the subject of negotiations within the Social Dialogue Council. If until 15th July (each year) the Trilateral Commission does not agree the minimum remuneration for the following calendar year, then the amount of the remuneration is determined by regulation of the Council of Ministers until 15th September (each year). It is significant that the remuneration determined by the latter cannot be lower than the amount suggested during the negotiations of the Trilateral Commission (Article 2 Section 5 in fine in connection with Article 2 Section 2 Subsection 1 of the Minimum Remuneration Act).

Another method of "cutting fiscal torts across" is an act of lesser significance which, in contrary to the statutory threshold, is of a mixed, quality and quantitative, nature and requires an assessment of the court

18 The Judgement of the Constitutional Tribunal of 20 February 2001, P 2/00, OTK 2001, no. 2, item 32 .

19 The Act of 28 July 2005 on amending the act - the Penal and Fiscal Code and certain other acts, Journal of Laws [Dz.U.] No. 178, item 1479. 
with an additional application of the criterion of the statutory threshold or the criterion of low value. According to the Penal and Fiscal Code, an act of lesser significance is a prohibited act as a fiscal petty offence which in a particular case, due to its specific circumstances - objective and subjective - features minor social harm, particularly when a reduced, or exposed to risk of reduction, public law liability does not exceed the statutory threshold according to Section 6 and the method and circumstances of committing a prohibited act do not indicate a flagrant disregard by the offender of the financial and legal order or rules of caution required in given circumstances, or the offender committing a prohibited act, the subject of which does not exceed the low value, due to reasons deserving consideration (Article 53 Section 8 of the Penal and Fiscal Code).

An act of lesser significance is obviously well-known in criminal law where it results in mitigated penal liability. Due to the lack of a statutory definition, the doctrine and judicature developed three different approaches towards this issue. ${ }^{20}$ One of them emphasises only objective features, the second approach includes subjective and objective features but also elements related to the offender, e.g., the criminal record, the behaviour before committing the crime and other elements which influence the penalty but are not the part of the act itself. Finally, according to the last conception, an act of lesser significance is an act of standard features with predominant mitigating elements of an objective and subjective nature. And this conception seems the most adequate in terms of penal fiscal law. When determining an act of lesser significance, there has to be considered a complex of mitigating elements of an objective and subjective nature related to the act which, by limiting the level of social harm (it has to be low but higher than negligible, and lower than that considered "not significant"), cause that the act becomes only a fiscal petty offence. ${ }^{21}$ According to the Penal and Fiscal Code, objective features particularly include: a) The value of the reduced, or exposed to risk of reduction, public law liability which does not exceed the statutory threshold; b) The value of the subject of the prohibited act which does not exceed low value (according to Article 53 Section 14 of

20 J. Jurewicz, "Kilka uwag w kwestii konstrukcji wypadku mniejszej wagi”, Acta Universitatis Lodziensis. Folia Linguistica 2004, no. 67, pp. 27-36.

21 See more: R.A. Stefański, "Okoliczności uzasadniające przyjęcie wypadku mniejszej wagi”, Prokuratura i Prawo 1996, no 12, p. 125 and literature cited therein. 
the Penal and Fiscal Code, low value is an amount which at the moment of committing a prohibited act does not exceed 200 times the minimum monthly salary); c) The method and circumstances of committing the act which suggest that there is no flagrant disregard by the offender of the financial and legal order or rules of caution required in given circumstances. Among subjective features, the elements which are emphasised the most are only the motives of acting of the offender which deserve consideration. $^{22}$ Therefore, it does not concern the motives for acting related to the intellectual sphere but an emotional factor, although on the grounds of fiscal crimes it would be more transparent and justified to refer to the motives. ${ }^{23}$ When determining an act of lesser significance the circumstances related to the offender, i.e., the opinion about the offender, the criminal record, the lifestyle, etc. As a rule, those circumstances shall influence the degree of penalty, although if they are not part of the act itself, they should not determine its category. According to the statutory definition, an act of lesser significance takes place when the act in concreto features a ow level of social harm, particularly if the reduced, or exposed to risk of reduction, public law liability does not exceed the statutory threshold or if another subject of the fiscal offence does not exceed low value. It should be emphasised that the Penal and Fiscal Code refers to social harm as such. By using the term "particularly", it is indicated in the Code that the estimation included in this regulation is only an example, therefore, when determining the degree of culpability, the authority should consider all quantifiers taken into account while assessing the degree of harm, indicated in Article 53 Section 7 of the Penal and Fiscal Code, which means the type and nature of the interest at risk or violated, the importance of the financial liability violated by the offender, the amount of the reduced, or exposed to risk of reducing, public law liability, the method and circumstances of committing a prohibited act, as well as the form of intention, the offender's motivation, the type of the violated rule of caution and the degree of its violation. ${ }^{24}$ If the court considered all circumstances and according to the court's assessment the level of social harm is "low" and a given provision states that

22 T. Grzegorczyk, op. cit., pp. 216-217.

${ }^{23}$ Ibidem, p. 217.

24 J. Sawicki, "Kryteria kwalifikacji wykroczeń skarbowych”, Nowa Kodyfikacja Prawa Karnego 2004, vol. 16, p. 337. 
in case of lesser significance of an act it is recognised as a fiscal petty offence - then the act should be classified as such.

The above-mentioned methods of so-called partial decriminalisation of fiscal torts are obviously not free from drawbacks. As for the criterion of statutory threshold as an instrument to identify fiscal petty offences, it is tenable, particularly in cases which concern a reduction or exposing to risk of reduction of a public law liability. Contrary to what one may expect, the problem is not the lack of the possibility of updating the idea behind this indicator in the offender's awareness, as it is sufficient to realise the binding amount of the minimum remuneration at the moment of committing the prohibited act, and know mathematical multiplication. ${ }^{25}$ The necessity of imprinting the amount of public law liability in the offender's mind, reduced or exposed to risk of reduction, carries more doubts. ${ }^{26}$ Obviously, the amount is the difference between the public law liability, paid by the offender, and the amount which was supposed to be paid, or - if the offender did not pay at all — the whole amount that was supposed to be paid. ${ }^{27}$ Such a requirement may be impracticable, which may suggest transferring liability to purely objective circumstances.

Another issue is that the mechanism of identifying fiscal torts on the basis of the minimum remuneration indicator does not really fit current social and economic conditions. It seems that a better solution would be to proportion the threshold amount to the average remuneration in the enterprise sector. It turns out that in many situations the average monthly remuneration constitutes an indicator for comparisons, transactions or settlements. In this way, pension assessment basis is calculated (Article 15 Section 4 of the Act of 17.12.1998 on pensions from the Social

25 Such doubts were once expressed by T. Bojarski, M. Szwarczyk, "Uwagi o projektowanym nowym prawie karnym skarbowym", [in:] Administracja publiczna u progu XXI w. Prace dedykowane Profesorowi Janowi Szreniawskiemu z okazji Jubileuszu 45-lecia pracy naukowej, ed. Z. Niewiadomski et al., Przemyśl 2000, pp. 100-101.

${ }^{26}$ L. Wilk, op. cit., p. 51.

27 T. Dębowska-Romanowska, "Uwagi o sposobie definiowania przedmiotu i podstawy opodatkowania z punktu widzenia obliczania prawidłowej (jednej i jedynej) kwoty podatku", [in:] Studia z dziedziny prawa podatkowego. Księga pamiatkowa ku czci Profesora Apoloniusza Kosteckiego, ed. B. Brzeziński et al., Toruń 1998, pp. 33-34. 
Security Fund ${ }^{28}$ ) or the judge's base salary (Article 91 Section 1c of the Act of 27.07.2001 - Law on the Common Courts System ${ }^{29}$ ). By taking into account the structure of an average remuneration in the enterprise sector, the legislator most often refers to the amount of this remuneration in II or III quarter of the previous calendar year, announced by the President of the Central Statistical Office in the form of a statement published in "Monitor Polski". However, in terms of the present reflections it is more important that the above-mentioned indicator shows volatility both upwards and downwards. If the amount of the average salary is dependent on the current economic condition, then in case of recession it may decrease. The situation is different when it comes to the minimum remuneration that increases annually, sometimes significantly. In order to respond more adequately to fiscal torts, a replacement of the current indicator with the average remuneration should be considered.

Some more objections appeared in the literature due to the structure of an act of lesser significance. First of all, there is clear incoherence in the regulations in Article 53 Section 3 and 8 of the Penal and Fiscal Code. According to the wording of the first provision, if the amount of the reduced, or exposed to risk of reduction, public law liability does not exceed the statutory threshold, the act becomes a fiscal petty offence. Assuming the above, it is not clear then why the other provision (Article 53 Section 8 of the Penal and Fiscal Code) orders to investigate if "the method and circumstances of committing a prohibited act do not indicate a flagrant disregard by the offender of the financial and legal order or rules of caution required in given circumstances. ${ }^{30}$ It is a completely unnecessary measure. According to both provisions, one may conclude that an act of lesser significance, in spite of the intention of the legislator, shall not play an important role in a situation when the amount of the reduced, or exposed to risk of reduction, public law liability or the value of the subject of a prohibited act does not exceed 5 times the amount of the minimum remuneration. However, it shall be applicable in all cases in which the public law liability or the value of the subject of a prohibited act exceeds 5 times the amount of the minimum remuneration but does not exceed 200 times its amount (low

\footnotetext{
${ }^{28}$ I.e. Journal of Laws [Dz.U.] of 2015, item 748 as amended.

${ }^{29}$ I.e. Journal of Laws [Dz.U.] of 2015, item 133 as amended.

${ }^{30}$ T. Bojarski, M. Szwarczyk, op. cit., pp. 100-101; L. Wilk, op. cit., p. 54.
} 
value - Article 53 Section 14 of the Penal and Fiscal Code) and for all prohibited non-consequential acts. ${ }^{31}$

The doubt regarding the final part of Article 53 Section 8 of the Penal and Fiscal Code seems equally justified. The legislator established that an act of lesser significance could take place also when the subject of the act does not exceed a low value (i.e., 200 times the minimum remuneration) and "the offender's motivation deserves consideration". There arises a question why the amount of the reduced, or exposed to risk of reduction, public law liability is limited in this provision by the amount of 5 times the minimum remuneration, and the value of the subject of the act -200 times. ${ }^{32}$ Additional doubts are connected with emphasising the assessment of the motives in the definition of an act of lesser significance, as well as the assessment of the disregard by the offender of the financial and legal order or rules of caution required in given circumstances (the assessment is supposed to lead to the decision if the motives deserve condemnation or the opposite - consideration, and if the disregard was "flagrant" or not). Imposing two more different criteria of the amount on such estimative terms which already provide a possibility of certain abuse -5 times or 200 times the minimum remuneration - seems completely unnecessary. It gives the impression of "overdefining" and causes that the definition of an act of lesser significance, instead of providing uniformity of penal fiscal judicial decision, brings the opposite. ${ }^{33}$

All this does not mean that the discussed methods of "cutting fiscal torts across" should be rejected. In spite of the reluctance of the criminal law doctrine towards partial discriminalisation, it cannot be omitted that most fiscal torts are directed against the Property of the State Treasury and local government units. If in the generally applicable law torts against the property have been differentiated for a long time in terms of the value of the property, therefore, it is justified all the more on the grounds of such a pragmatic branch as penal fiscal law. Somehow we are still forced to divide penal fiscal torts, using both the amount criterion and the act of lesser significance. Particularly, the latter would be difficult to reject. The legislator consequently differentiates fiscal torts "concerning the reduction

31 J. Michalski, op. cit., p. 118.

32 L. Wilk, op. cit., p. 54.

33 Ibidem, pp. 54-55. 
of the public law liability" and fiscal torts for which "the public law liability was reduced". ${ }^{34}$ The legislator reserve the structure of an act of lesser significance for the latter (e.g., Article 60, 61, 64, 74 of the Penal and Fiscal Code). Due to the fact that such torts do not concern a reduction of the public law liability - another thing is that committing them may result in such a reduction in the future - their division with the use of the numerical threshold was legislatively impossible. Therefore, it can be stated that the criterion of material differentiation sanctions only this state of affairs, implementing - in relation to the types of acts, the statutory definitions of which do not include a feature of reduction of public law liability - some restrictions of prosecuting due to purpose and technical reasons. Only highly developed casuistry of penal fiscal regulations would allow to avoid a necessity of using the "cutting across" criterion in the form of the act of lesser significance. Needless to say, such an alternative has not been possible to accept so far. Therefore, instead of rejecting the act of lesser significance, its definition should be simplified. It seems that in this regard it would be sufficient to settle for the first part of the definition, which is the expression that according to the Code, an act of lesser significance is a prohibited act as a fiscal petty offence which in a certain case, due to its specific circumstances - both objective and subjective - features a low level of social harm of the act. ${ }^{35}$ Further clarifying is rather senseless.

\section{References}

Bojarski T., Szwarczyk M., "Uwagi o projektowanym nowym prawie karnym skarbowym", [in:] Administracja publiczna u progu XXI w. Prace dedykowane Profesorowi Janowi Szreniawskiemu z okazji Jubileuszu 45-lecia pracy naukowej, ed. Z. Niewiadomski, J. Buczkowski et al., Przemyśl 2000.

Dębowska-Romanowska T., "Uwagi o sposobie definiowania przedmiotu i podstawy opodatkowania z punktu widzenia obliczania prawidłowej (jednej i jedynej) kwoty podatku", [in:] Studia z dziedziny prawa podatkowego. Księga pamiatkowa ku czci Profesora Apoloniusza Kosteckiego, ed. B. Brzeziński et al., Toruń 1998.

Dębski R., Pozaustawowe znamiona przestępstwa, Łódź 1995.

${ }^{34}$ See more: G. Łabuda, T. Razowski, "Glosa do postanowienia SN z dnia 27 marca 2003, sygn. akt I KZP 2/03”, Prokuratura i Prawo 2003, no. 11, pp. 125-127.

${ }^{35}$ L. Wilk, op. cit., p. 55; O. Włodkowski, "Wypadek mniejszej wagi w Kodeksie karnym skarbowym”, Monitor Podatkowy 2014, no. 7, pp. 22-29. 
Grzegorczyk T., Kodeks karny skarbowy. Komentarz, $2^{\text {nd }}$ ed., Warszawa 2001.

Jurewicz J., "Kilka uwag w kwestii konstrukcji wypadku mniejszej wagi", Acta Universitatis Lodziensis. Folia Linguistica 2004, no. 67.

Łabuda G., Razowski T., "Glosa do postanowienia SN z dnia 27 marca 2003, sygn. akt I KZP 2/03", Prokuratura i Prawo 2003, no. 11.

Marek A., [in:] System prawa karnego. Zagadnienia ogólne, vol. 1, ed. A. Marek, Warszawa 2010.

Michalski J., Komentarz do kodeksu karnego skarbowego. Tytut I. Przestepstwa skarbowe $i$ wykroczenia skarbowe, Warszawa 2000.

Prusak F., Prawo i postepowanie karne skarbowe, $2^{\text {nd }}$ ed., Warszawa 2002.

Sawicki J., "Kryteria kwalifikacji wykroczeń skarbowych", Nowa Kodyfikacja Prawa Karnego 2004, vol. 16.

Siwik Z., Systematyczny komentarz do ustawy karnej skarbowej. Część ogólna, Wrocław 1993.

Stefański R.A., "Okoliczności uzasadniające przyjęcie wypadku mniejszej wagi”, Prokuratura i Prawo 1996, no. 12.

The judgement of the Constitutional Tribunal of 26 April 1995, K 11/94, OTK 1995, no. 1, item 12 .

The judgement of the Constitutional Tribunal of 20 February 2001, P 2/00, OTK 2001, no. 2 , item 32 .

Wilk L., Szczególne cechy odpowiedzialności za przestępstwa i wykroczenia skarbowe, Katowice 2006.

Wilk L., Zagrodnik J., Prawo karne skarbowe, Warszawa 2009.

Włodkowski O., "Wypadek mniejszej wagi w Kodeksie karnym skarbowym", Monitor Podatkowy 2014, no. 7.

\section{Summary}

The author considers the issue of differentiation of fiscal torts. The author pays particular attention to the criterion of statutory threshold and an act of lesser significance. During the detailed analysis of both definitions, the author indicates deficits and drawbacks in terms of their statutory regulations. The critical comments allow the author to formulate proposals of changes in this normative area.

Keywords: fiscal petty offence, fiscal offence, act of lesser significance, statutory threshold. 